Meta

Journal des traducteurs

Translators' Journal

\title{
When Translation Competence Is Not Enough: A Focus Group Study of Medical Translators
}

\section{Matilde Nisbeth Brøgger}

Volume 62, numéro 2, août 2017

URI : https://id.erudit.org/iderudit/1041030ar

DOI : https://doi.org/10.7202/1041030ar

Aller au sommaire du numéro

\section{Éditeur(s)}

Les Presses de l’Université de Montréal

\section{ISSN}

0026-0452 (imprimé)

1492-1421 (numérique)

Découvrir la revue

Citer cet article

Nisbeth Brøgger, M. (2017). When Translation Competence Is Not Enough: A Focus Group Study of Medical Translators. Meta, 62(2), 396-414.

https://doi.org/10.7202/1041030ar

\section{Résumé de l'article}

Les approches fonctionnalistes de la traduction ont conduit à une modification du statut et du rôle du traducteur : le traducteur est maintenant considéré comme un agent actif responsable du processus de communication, ce qui accentue l'importance de l'expertise et de la compétence en traduction. La compétence en traduction a donc soulevé un intérêt croissant chez les chercheurs, or, la plupart des études ont été menées dans des environnements contrôlés, sans tenir compte du contexte de traduction dans lequel travaillent habituellement les traducteurs professionnels. La présente étude établit l'importance du contexte de traduction dans l'investigation de la compétence en traduction. Basée sur une précédente étude de traductions de notices d'information des patients ayant révélé un manque de compétence en traduction, elle fait intervenir la perception vécue des traducteurs et s'appuie sur la méthode des groupes de réflexion. Les résultats démontrent le fort impact des contraintes contextuelles sur les processus de travail du traducteur médical, et donc sur les produits. En conclusion, l'étude établit qu'une analyse isolée des produits de traduction risque de produire une image déformée de la compétence des traducteurs.
Ce document est protégé par la loi sur le droit d'auteur. L’utilisation des services d'Érudit (y compris la reproduction) est assujettie à sa politique d'utilisation que vous pouvez consulter en ligne.

https://apropos.erudit.org/fr/usagers/politique-dutilisation/ 


\title{
When Translation Competence Is Not Enough: A Focus Group Study of Medical Translators
}

\author{
MATILDE NISBETH BRØGGER \\ Aarhus University, Aarhus, Denmark \\ matnj@bcom.au.dk
}

\begin{abstract}
RÉSUMÉ
Les approches fonctionnalistes de la traduction ont conduit à une modification du statut et du rôle du traducteur: le traducteur est maintenant considéré comme un agent actif responsable du processus de communication, ce qui accentue l'importance de l'expertise et de la compétence en traduction. La compétence en traduction a donc soulevé un intérêt croissant chez les chercheurs, or, la plupart des études ont été menées dans des environnements contrôlés, sans tenir compte du contexte de traduction dans lequel travaillent habituellement les traducteurs professionnels. La présente étude établit l'importance du contexte de traduction dans l'investigation de la compétence en traduction. Basée sur une précédente étude de traductions de notices d'information des patients ayant révélé un manque de compétence en traduction, elle fait intervenir la perception vécue des traducteurs et s'appuie sur la méthode des groupes de réflexion. Les résultats démontrent le fort impact des contraintes contextuelles sur les processus de travail du traducteur médical, et donc sur les produits. En conclusion, l'étude établit qu'une analyse isolée des produits de traduction risque de produire une image déformée de la compétence des traducteurs.
\end{abstract}

\section{ABSTRACT}

Functionalist approaches to translation brought about a shift in the status and role of the translator: the translator is now considered to be an active, responsible agent in the communication process, which increases the importance of translation expertise and translation competence. Translation competence has thus attracted mounting research interest; however, empirical studies have primarily been conducted in controlled environments, omitting the translation context that professional translators usually work within. This study offers empirical evidence of the importance of the translation context when investigating translation competence. Based on a previous empirical study of translated Patient Information Leaflets, which showed a lack of translation competence, this study includes the translators' perception using the focus group methodology. Results show the strong influence of contextual constraints on medical translators' processes and thus products. The study concludes that an analysis of translation products alone may give a skewed picture of translators' competence.

\section{RESUMEN}

Los enfoques funcionalistas de la traducción han producido un cambio del estatus y del papel del traductor: ahora el traductor es considerado como un agente activo y responsable en el proceso de comunicación, lo que acentúa la importancia de la pericia traductora y la competencia traductora. Por lo tanto, la competencia traductora ha atraído un interés creciente de investigación. Sin embargo, los estudios empíricos se han llevado a cabo principalmente en entornos controlados sin tener en cuenta el contexto de la traducción en el que suelen trabajar los traductores profesionales. Este estudio ofrece evidencia empírica de la importancia del contexto de la traducción en la investigación de la competencia traductora. Basándose en un estudio empírico previo de Folletos de Información para el Paciente traducidos, que ha revelado una falta de competencia tra- 
ductora, este estudio incluye la percepción de los traductores utilizando la metodología de grupos focales. Los resultados muestran la fuerte influencia de las restricciones contextuales en los procesos de trabajo de los traductores médicos y, por tanto, en los productos. El estudio concluye que un análisis aislado de los productos de traducción puede dar una imagen sesgada de la competencia de los traductores.

\section{MOTS-CLÉS/KEYWORDS/PALABRAS CLAVE}

compétence en traduction, traduction médicale, contraintes de traduction, groupe de réflexion, agentivité

translation competence, medical translation, translational constraints, focus group, agency

competencia traductora, traducción médica, restricciones de traducción, grupo focal, agencia

\section{Introduction}

One of the main notions in functionalist approaches to translation is that the translator is a responsible agent and an expert in translational action (Vermeer 2004). These suppositions assume a certain level of translation competence (TC). TC has been widely discussed theoretically (Neubert 1994; Chesterman 1997; Pym 2003; Alves 2005) and researched empirically (PACTE 2000; 2002; 2003; 2005; 2009; 2011). The research designs of most empirical studies into TC have been experimental in nature, and performed in controlled settings. While these studies have yielded valuable results, there is insufficient understanding of how TC unfolds in context, and how context might influence the translator's ability to be a competent expert, as reflected both in the translation process and in the product.

The translation context, and its potentially constraining influence, has been given extensive attention within approaches such as polysystem theory (Even-Zohar 1979) and in anthologies such as Translation and Power (Gentzler and Tymoczko 2002) and Agents of Translation (Milton and Bandia 2009); however, the focus has almost exclusively been on literary translation. Within non-literary LSP translation, the influence of context has received less attention, resulting in a shortage of studies of how TC might be influenced by the translation context in LSP translation.

This article takes as its point of departure a translation product study (Nisbeth Jensen and Zethsen 2012; Nisbeth Jensen 2013), which found many problematic translation choices in relation to the skopos. The study analyzed 54 translated Patient Information Leaflets (PILs), which are the texts provided inside medication packages in the EU context, informing users about dosage, side effects, etc. The study found that the translators had not only transferred, but also introduced elements that made the target texts less comprehensible than the source texts. Comprehensibility is of paramount importance as PILs must be "written and designed to be clear and understandable, enabling the users to act appropriately" (European Parliament and Council 2001). On the basis of this product study, one might conclude that the choices made are evidence of a lack of translation competence; however, a product study does not shed light on the reasons for these choices. In order to understand the underlying reasons behind the translators' strategies, PIL translators need to be actively involved. Thus, this study aims to investigate PIL translators' approaches to PIL translation, including how their translation competence and expertise might be influenced by 
the context. The methodology involved a focus group study with PIL translators to investigate their conceptions concerning PIL translation and comprehensibility.

In the following, the background of the study is described, with special focus on the PIL genre; the focus group method is introduced along with the research design of the study; the results are presented, and the consequences of contextual constraints on translators' competence are discussed; finally, the article concludes with a recommendation for future studies of TC.

\section{Background: Comprehensibility in PILs and translation competence}

PILs ${ }^{1}$ are mandatory texts in the EU, which means they must accompany all medication. They inform users about dosage, side effects, etc. in order to foster informed decision-making and patient empowerment. Despite the legal requirement that PILs must be clear, understandable and enable the users to act appropriately, they are infamously difficult to understand (Consumers' Association 2000; Askehave and Zethsen 2000; 2002; 2003; 2010; Dickinson, Raynor et al. 2001; Harwood and Harrison 2004; Raynor 2007; Pander Maat and Lentz 2010). Several studies have shown that PILs translated from English into Danish are more linguistically complex than their source texts, and thus less likely to be comprehensible for their users (Askehave and Zethsen 2002; Nisbeth Jensen and Zethsen 2012; Nisbeth Jensen 2013). Several explanations for this increase in complexity have been offered; for example, the fact that the PIL is a mandatory, regulated genre (Askehave and Zethsen 2003), and the potentially competing interests between providing correct and comprehensible patient information and ensuring a fast and smooth marketing approval procedure by staying close to the source text (Askehave and Zethsen 2002). Perhaps the most important explanation, according to Askehave and Zethsen (2002), is that many PILs are translated by pharmacists, who may not have the necessary translation competence.

This was the point of departure of the above-mentioned product study, which analyzed 54 PILs (27 translated by pharmacists, 27 translated by professional translators). The study found significantly more problematic Latin-based terms and nominalizations in the pharmacist corpus than in the professional translator corpus (Nisbeth Jensen and Zethsen 2012). However, translations from both translator groups included many elements that make the translations less comprehensible than the source texts (Nisbeth Jensen 2013).

According to functionalist approaches such as skopos theory, it is the translator's main task to produce a target text that satisfies the expectations of the target text receivers. It is thus the translator who has to decide how to operationalize a translation skopos in the given situation. On the basis of the described product study, one might conclude that both the pharmacists and professional translators who translated the PILs failed to live up to the requirements of an expert translator as they seem to lack the translation competence to fulfill the skopos. To investigate whether there might be other reasons for the problematic translation choices, two focus group interviews were conducted. In the following, the focus group method and the conducted study are described. 


\section{The focus group method}

The focus group method was chosen to explore qualitatively the reasons and logics given by PIL translators for various translation choices. As argued by Koskinen (2008), the focus group method has not been used very extensively within Translation Studies even though a study by Schjoldager and Zethsen found that:

The focus group method seems an excellent tool for the exploratory study of translators' self-perception, norms, and working conditions: it elicits data in a less controlled way than more traditional methods and encourages subjects to react to other people's views, thereby making information available that might otherwise have remained unarticulated; it seems to reduce the risk of researcher interference; and it seems to help researchers keep an open mind. (Schjoldager and Zethsen 2003: 150; my emphasis)

This quote clearly underlines the usefulness of the focus group method as a means to investigate translators' norms and working conditions, two elements which are relevant for the purpose of this study. Furthermore, according to Koskinen (2008), the focus group method is a suitable method for producing qualitative data on translators' shared attitudes, beliefs, group dynamics and group norms. As PIL translation occurs in a context characterized by legislation, pre-determined processes and multiple agents, the relevant context needs to be included to understand the translation process behind the translation choices: this is made possible through focus groups (Halkier 2009). Finally, as suggested by Angelelli (2006: 179-180) in her study of healthcare interpreters, focus groups are a "valuable mechanism for asking participants to comment on and suggest explanations for research findings." A focus group study was thus deemed a suitable method to provide explanations for the findings in the product study.

\subsection{Participants}

Two focus groups were conducted: one focus group consisting of five professional translators (see Table 1), and a second focus group consisting of five pharmacists (see Table 2). Mixing the two groups was purposefully avoided to prevent potential conflicts and repression of views (Bloor, Frankland et al. 2001). Most of the literature on focus group recruitment emphasizes the importance of group composition and selection of participants (Bloor, Frankland et al. 2001); however, because the Danish PIL translator population is quite small, only two main recruitment criteria were used:

- the participant had to be either a professional translator or a pharmacist.

- the participant had to have PIL translation experience.

This also meant that it was not possible to only recruit PIL translators whose PILs had been analyzed in the above-mentioned study or to pair the analyzed PILs with specific translators in the focus groups. Prior to the focus groups, translators received a letter of invitation, which explained the purpose of the focus groups, and two copies of the consent form (one to be signed and returned, the other for their own records). 
TABLE 1

Participants in translator focus group

\begin{tabular}{|c|c|c|c|c|c|}
\hline \multicolumn{6}{|c|}{ Focus group 1 - Professional translators } \\
\hline $\mathrm{Name}^{2}$ & $\begin{array}{l}\text { Educational } \\
\text { background }\end{array}$ & $\begin{array}{l}\text { Medical/ } \\
\text { pharmaceutical } \\
\text { training }\end{array}$ & $\begin{array}{l}\text { Other relevant } \\
\text { training }\end{array}$ & $\begin{array}{l}\text { Years of } \\
\text { experience }\end{array}$ & $\begin{array}{l}\text { Number of PILs } \\
\text { translated }\end{array}$ \\
\hline T-Jonas & $\begin{array}{l}\text { State-authorized } \\
\text { translator, cand. } \\
\text { ling.merc }{ }^{3}\end{array}$ & - & - & 15 & 50 \\
\hline T-Torben & $\begin{array}{l}\text { State-authorized } \\
\text { translator, cand. } \\
\text { ling.merc }\end{array}$ & $\begin{array}{l}\text { Only through } \\
\text { translation }\end{array}$ & - & 14 & $25-50$ \\
\hline T-Annika & $\begin{array}{l}\text { State-authorized } \\
\text { translator, cand. } \\
\text { ling.merc }\end{array}$ & - & - & 5 & $\begin{array}{l}10-20 \text { (but } \\
\text { primarily } \\
\text { reviewing) }\end{array}$ \\
\hline T-Cathrine & $\begin{array}{l}\text { State-authorized } \\
\text { translator, cand. } \\
\text { ling.merc }\end{array}$ & $\begin{array}{l}\text { Course in } \\
\text { medical } \\
\text { terminology }\end{array}$ & - & 12 & $\begin{array}{l}1000 \text { (translation } \\
\text { and review) }\end{array}$ \\
\hline T-Lone & $\begin{array}{l}\text { Translator, cand. } \\
\text { mag }^{4}\end{array}$ & $\begin{array}{l}\text { Two years' } \\
\text { medicine, minor } \\
\text { in sports science }\end{array}$ & $\begin{array}{l}30 \text { years' } \\
\text { experience in } \\
\text { specifically } \\
\text { medical } \\
\text { translation }\end{array}$ & 30 & $1000-2000$ \\
\hline
\end{tabular}

TABLE 2

Participants in pharmacist focus group

\begin{tabular}{|c|c|c|c|c|c|}
\hline \multicolumn{6}{|c|}{ Focus group 2 - Pharmacists } \\
\hline Name & $\begin{array}{l}\text { Educational } \\
\text { background }\end{array}$ & $\begin{array}{l}\text { Translation } \\
\text { training }\end{array}$ & $\begin{array}{l}\text { Other relevant } \\
\text { training }\end{array}$ & $\begin{array}{l}\text { Years of } \\
\text { experience }\end{array}$ & $\begin{array}{l}\text { Number of PILs } \\
\text { translated }\end{array}$ \\
\hline P-Hanne & $\begin{array}{l}\text { Pharmacist, cand. } \\
\text { pharm }^{5}\end{array}$ & - & $\begin{array}{l}23 \text { years in } \\
\text { pharmacy, } \\
\text { customer } \\
\text { contact, } \\
\text { communication } \\
\text { about medicine }\end{array}$ & 23 & $\begin{array}{l}500-1000 \text { (has } \\
\text { drafted the same } \\
\text { quantity in } \\
\text { Danish) }\end{array}$ \\
\hline P-Louise & $\begin{array}{l}\text { Pharmacist, cand. } \\
\text { pharm }\end{array}$ & - & - & 14 & $\begin{array}{l}200+ \\
\text { (partly) }\end{array}$ \\
\hline P-Katja & $\begin{array}{l}\text { Pharmacist, cand. } \\
\text { pharm }\end{array}$ & - & $\begin{array}{l}15 \text { years of } \\
\text { experience, } 2 \frac{1}{2} 2 \\
\text { day course }\end{array}$ & 35 & $\begin{array}{l}200+ \\
\text { (fully + partly) }\end{array}$ \\
\hline P-Kristine & $\begin{array}{l}\text { Pharmacist, cand. } \\
\text { pharm }\end{array}$ & - & - & 6.5 & 50 \\
\hline P-Vibeke & $\begin{array}{l}\text { Pharmacist, cand. } \\
\text { pharm }\end{array}$ & - & $\begin{array}{l}\text { Six years of } \\
\text { experience in } \\
\text { Regulatory } \\
\text { Affairs with } \\
\text { translation/ } \\
\text { reviews }\end{array}$ & 8 & 50 \\
\hline
\end{tabular}

\subsection{Interview guide}

Discussion topics were organized in an interview guide based on the results of the product study mentioned above, with special focus on investigating the reasons for translation choices that were detrimental to comprehensibility. The focus group followed the funnel model (Morgan 1996), starting with a few open questions to 
encourage participants to speak from their own experiences, followed by more specific starter questions as well as focused follow-up questions.

The three main topics were: 1) Translation of PILs and the process. This topic was introduced to gain an understanding of the translation process of PILs as conceptualized by the translators in order to investigate what they see as the purpose of PILs and PIL translation, and to understand the context, i.e. whether they receive instructions and whether they use any tools. 2) The receiver group of PILs. This topic was used to investigate the translators' perception of the PIL receiver and to investigate their conception of comprehensibility, what they do to ensure it, and how they tailor the language for the receiver. Also, this topic was introduced to prompt the participants to talk about their approach to translation. 3) The role of the translator. This topic was introduced to facilitate the focus group participants to share their opinions about the role of the translator in relation to PIL translation, among other things to gain an understanding of the expertise of the translator and the degree of power or freedom the translator finds that they have. After these broad general questions, following the funnel model, the focus group interview guide addressed more specific questions. These included discussing the possible translation choices for English source texts elements (e.g. the Latin-based terms osteoporosis, menopause, oral, as well as grammatical choices such as nominalizations, compound nouns, etc.), and discussing different Danish target text options.

Apart from the five participants and the present author in the role of moderator, a colleague attended the focus groups to take general notes on group dynamics and non-verbal behavior.

\subsection{Analysis}

The data were transcribed and analyzed using the qualitative research software NVivo. Thematic analysis was employed, enabling the identification and analysis of themes in texts (Braun and Clarke 2006). The analysis of the identified themes was carried out twice in order to ensure consistency in the analytical procedure. When presenting the results, Brinkmann and Kvale's recommendations concerning interview quotes have been followed (Brinkmann and Kvale 2009); thus, the originally oral quotes are presented in a written style. All quotes are translated from Danish by the author using a functional approach. The main skopos was to ensure that the meaning of the quotes is conveyed to the reader while still conveying the formulations made by the participants as closely as possible.

\section{Results}

Early in the course of the focus groups, it became clear how extensive the contextual constraints surrounding PIL translation are, and how limited the PIL translators felt by these. Even though the participants were only explicitly asked about constraints in the opening question (they were asked about their experiences with the translation of PILs; what they found interesting, easy, difficult; and, whether they meet challenges or constraints, etc.), the results show the importance and negative influence of contextual factors on the translation product; contextual constraints were discussed much more extensively in both groups than intratextual, translation issues. The fol- 
lowing overview of results focuses on the contextual constraints that were detrimental to the quality of the target texts. The constraints can be grouped into two overall categories: problems linked to the legal requirements surrounding the translation process, and problems stemming from the influence of other agents in the translation context.

\subsection{Legal authorization process}

The first four constraints are of a procedural nature and linked to the legal authorization process:

- The use of PIL templates and national guidelines

- The status of the source text

- Extensive amendments

- Temporal constraints

\subsubsection{The use of PIL templates and national guidelines}

Both focus groups discussed the constraining nature of the EU template, which specifies headings, sub-headings and text structure. The PIL translators felt limited in their formulations, as the template forces the translators to use sub-optimal expressions that contain typos, incomprehensible sentences, and words that could be expressed in more comprehensible ways:

P-Katja: We're very bound by some locked-in sentences that have been authorized through the European registration process [...]

T-Lone: We're extremely locked-in given that EMA's texts must be ... more or less maintained. That constrains us a lot in our choice of words and in our way of expressing ourselves [...]

Even though the translators sometimes make arguments against the template, some clients want to follow it blindly:

T-Annika: There are templates you have to follow, which only some of them want you to follow, and then there are some who are so keen on us following them that when they look at the template, they don't even see what it actually says.

It is not only the EU template that is seen as problematic and constraining for the translation process and hence the product; the pharmacists also find the national guidelines constraining for their process:

P-Katja: [...] According to the Danish Drug Standards, we are required to call it oral opløsning [oral solution; oral is the expert term in Danish].

P-Hanne: Lactose is not spelt with a $k$ at the moment [Danish spelling would normally use a $k$ while $c$ is the English spelling]. That one goes back and forth.

Moderator: Okay. According to...?

P-Louise: According to the Danish Drug Standards. It states how we have to translate from English.

The problem with having to follow these European and national standards is that sometimes the linguistic quality is not good, which means that poor linguistic choices 
are recycled in PILs, affecting comprehensibility. Both groups of translators cited this as the main problem of being restricted by the templates:

T-Lone: EMA's texts are - excuse me - not the best language I've seen *laughter*. There are typos. There are hopeless expressions, totally incomprehensible sentences, which, in my opinion, become worse and worse every time they change them.

One example is a spelling mistake, which according to T-Lone has been in the Danish template for a long time despite her commenting on it several times:

T-Lone: I think I've pointed out a mistake at the bottom of the PIL at least 20 times where it states indehold [correct Danish spelling indhold] [T-Jonas: Mmm]. I've been correcting it for three years, every time. And every time they say "yes, we've said it to the client." But it makes no difference; I have to do it every time anyway.

T-Lone tries to exercise her expertise and her role as a translator, but she finds that nothing gets changed. An example related to the lack of idiomaticity in the templates concerns the use of the personal pronoun you:

P-Louise: And it says your doctor. We don't say it like that in Danish.

P-Hanne: No, we say the doctor.

Others: Yes.

P-Louise: But that is what the template would write: your doctor.

P-Hanne: That's modern right now.

Others: Yes.

The pharmacists are also frustrated by the fact that the newest template dictates that they should use the term lægemiddel [medicinal product] instead of the more straightforward medicin [medicine]:

P-Louise: Medicin. We should use medicin in PILs.

P-Katja: Oh yeah.

P-Louise: But the funny thing is that in the newest template, the word lægemiddel has been introduced into the PIL.

One translator, T-Torben, argues that the constraints do not necessarily lie in the legal regulations, but in the client's interpretation of the constraints:

T-Torben: We're maybe not so bound by EU regulations but rather by the client's interpretation of these regulations.

This indicates that there might actually be more freedom within the regulations than assumed by clients at the pharmaceutical companies.

\subsubsection{The status of the source text}

The status of the source text was found by the PIL translators to be detrimental to comprehensibility because - as argued by the pharmacists - sometimes the source texts are written within an exclusively English context; they argue that they seem to be produced by a person with limited knowledge of translation who would therefore not know whether or not the text can be easily translated. One could argue that this is not relevant, as the translators should have the competence to deal with any source 
text. However, for PILs, the translation must be source text-oriented because this is the text that has been authorized. This can be problematic, especially because the PIL translators did not find that it was sufficiently clear how much deviation from the source text is accepted. This is also stated by one of the pharmacists with many years of experience within the field:

P-Louise: It's because it comes from English, and we're actually very bound by the fact that we mustn't deviate from the English text because it's the one that is authorized by the European health authorities. So we're not allowed to deviate at all. Because then we suddenly have something in our PILs that isn't authorized. And that's where the fine balance comes in, which I still find difficult ${ }^{*}$ everyone nods in agreement ${ }^{*}$, even after seven years in this job. Knowing how much I can deviate, you know; when the deviation I make is actually okay [...]

The problems experienced by the participants in the professional translator group are linked to the client's fear that deviations from the ST, even though they lead to better quality texts, might not be authorized:

T-Cathrine: We've also experienced some clients who've been a little afraid to deviate from the source text, and who've said "but you have to stick to what it says as closely as possible" even though you've said "but it doesn't really make sense in Danish to do a word-to-word translation." [...] they're afraid to deviate too much or that you've made interpretations of some sentences...because again, they don't think that they can get it authorized.

Actually, most of the PIL translators would prefer to produce the Danish PIL from scratch instead of translating, as this would result in a better text.

T-Annika: [...] if you were to do all of it from scratch, and you didn't need to think about the fact that it was an English PIL and translate what it said, you'd definitely write in a completely different style and combine the sentences a little differently, and it'd look completely different [...]

P-Hanne: I think that the national PILs - where we write them almost exclusively ourselves based on the Summary of Product Characteristics without an English source - are much easier. It's easier keeping it to language suitable for the average citizen who needs this information - My mother-in-law for example.

\subsubsection{Extensive amendments}

The focus group participants discussed the fact that small segments of the PIL are often amended, which has consequences for the comprehensibility and cohesion of the texts. One participant, P-Katja, states:

Sometimes we're up to amendment number 87 for a product that has had a lifetime of only 10 years.

These amendments cause several problems for the translation process and product as will be discussed below. Several participants in the translator focus group mentioned that sometimes they are unable to change an expert medical term into a Danish lay term because they are only allowed to work with the small part of the text which is being amended:

T-Cathrine: I often think that what we get is an update to a PIL, and then we're limited by the fact that we have to follow what is translated already. Then you sometimes have a conflict. I mean, would you continue with something when you think it isn't very 
good, but at least it'll be consistent? Or should you improve it and run the risk of getting it back with a message that it's no good because you haven't been consistent in your terminology?

Therefore, when the translators are given only amendments, they find that their expertise is constrained because they might have to give good text quality and comprehensible language a lower priority than consistency and a quick authorization process. The participants also mention that the extensive number of amendments poses challenges to the fluency of the text:

P-Katja: And then there are many small segments in the Summary of Product Characteristics [which then have to be implemented in the PILs] that are changed from time to time. And that makes it very difficult to write a text that flows naturally because, at the same time, you receive very strict rules that state that you're only allowed to change the text segments that are in red in English in the Danish text.

The above quote shows the extensiveness of amendments; another pharmacist, $\mathrm{P}-\mathrm{Hanne}$, also argues that the amendments are time-consuming without having a positive impact on the text in relation to the receiver:

P-Hanne: I sometimes think that the PILs with amendments are one of the things that we spend a lot of time on; the templates are changed, and suddenly someone has decided that something has to be described in a different way ...Unfortunately, however, our work doesn't result in an "Aha!" moment for the end user.

This frustration is shared by P-Louise, who argues that the amendments take focus away from comprehensible language:

P-Louise: We actually spend a lot of time on nitty-gritty things. What we're describing here has nothing to do with translation. And because we have these very strict deadlines, that is what we end up spending our time on instead of looking at the language.

Thus, the extensive number of small amendments is argued to be detrimental to the comprehensibility of the translation; further, the PIL translators are not allowed to change other parts of the PIL, which might contain problematic elements such as incomprehensible medical terms. The participants also stated that the extensive amendments take time and focus away from linguistic changes that could improve comprehensibility for PIL receivers.

\subsubsection{Temporal constraints}

In the EU procedure, the English PIL is the authorized version, and within five days of that authorization, the pharmaceutical company must provide the European Medicines Agency (EMA) with the translations of several documents - including PILs - in all EU languages. This means that the pharmaceutical companies only have five days to provide 23 translations of various texts, which are subsequently reviewed by the various national authorities, in this case the Danish Health and Medicines Authority (DHMA). Similarly, after linguistic review of the Danish PIL by the DHMA, the pharmaceutical company has a maximum of three days to implement the DHMA's comments and corrections before having to resubmit to EMA. Because of the strict deadlines, the focus group participants said they have to live with some sub-optimal choices because there is insufficient time to talk to translation clients or with the reviewers at the DHMA. 
P-Katja: There are very short time deadlines, so it's a massive challenge to write proper PILs; they're authorized through a central registration procedure where we receive the English text on Friday, and by Monday morning or afternoon, we have to have a final text.

One of the pharmacists also explains that there is pressure not to be the country responsible for delaying the process:

P-Louise: [...] I think that playing around with the language is extremely interesting, trying to see how I get something to sound comprehensible based on this strange English text. But the challenge is that there isn't always time for it. And then it has to be sent off. And those deadlines are extremely important, especially in the European procedures, because if you don't submit your things on time, you risk Denmark being responsible for delaying some important authorization. You don't want to be responsible for that, so we all try to meet the deadlines.

These strict and short deadlines mean that time is a factor, leading to potential problems for optimal tailoring to lay people:

P-Hanne: Of course, you have the possibility of talking to the person who does the linguistic review [at the DHMA]. The problem is just that you get the text Friday afternoon and then it has to be delivered by noon on Monday. You don't have time to go over it again and again, and agree on everything. But if you have some issue where you really think "no I can't live with that," then we can do it, of course. But we don't have much time.

P-Kristine: No, I often think we just give in, you know, because...

P-Hanne: Yes, it's the quickest option.

P-Kristine: You don't have time to discuss it.

The translators also argue that time is spent on elements other than making a good translation, such as copying information into almost identical PILs of different pharmaceutical strengths:

P-Louise: For many of our ones [PILs] - and it's probably the same with yours too - if there are different strengths, you have to copy all the amendments into all the different strengths. Because an amendment is often the same for all the elements ... the texts are structured very differently. And this process of making sure that you get it all incorporated correctly into all these strengths - it's also very time-consuming. That can sometimes be more time-consuming than the translation itself, at least for some of the texts we have [Others: Yes], because we have so many similar ones where everything is repeated. So that only adds to the time pressure, which results in the translation sometimes being one of the things you need to do quickly because you also need to have time for all your quality assurance.

The quote by P-Louise highlights that time is spent on other issues than tailoring for the receiver, as the translation phase needs to be finalized as quickly as possible. When talking about the reference material that translators sometimes receive, T-Torben and T-Lone also mention the short deadlines:

T-Torben: Yes, if it's an amendment that has to be done, it's a little intense receiving 17 PDFs, which you don't really know how to use, or whether or not you have to read them or just glance quickly over them.

T-Lone: And then 24 hours to do it.

*laughter* 
Only the participants in the professional translator group mention issues concerning financial constraints in PIL translation. While the translators were discussing problematic terms in PILs they were asked what they do about such terms - whether they have the option of talking to their client:

T-Jonas: [...] there is also the financial angle to what we do, right? When you're young and idealistic, you want to point out everything; then, at some point, you think that if no one wants to pay for it, you can learn to live with the mistakes - if you've pointed it out several times, you get fed up in the end.

Thus, if the client does not want to pay for the expertise of the translator or listen to the advice given by the translator, the quality of the final product may suffer.

\subsection{Other agents in the translation context}

In addition to the problems linked to the broader translation process, the participants also extensively discussed constraints relating to the influence of other agents in the translation context, i.e. clients and linguistic reviewers at the Danish Health and Medicines Authority (DHMA). The constraints were especially linked to the following issues:

- Lack of language and translation awareness from clients

- Problematic linguistic review at the DHMA

\subsubsection{Lack of language and translation awareness from clients}

The translators noted a lack of language and translation awareness on the part of the clients, leading to constraints in the translation process, especially if the translator and the client have different conceptions of translation quality:

T-Cathrine: Yes, they say that it's authorized, and they've called it that before; it's written in the versions that they've had for many years. It could also be because they want it to be called that, and then, of course, you just have to say: "Hmmm, that is fair enough," and then you have to use that term. It could also be that they don't understand the reasons why we want it changed. And they can't [...] it comes back to the question of what is meant by linguistic quality. If you tell them, "but it's because we'd like to increase the quality, change the quality," they reply, "but this is good enough for us like this." Then all you can do is say okay. There are, of course, many times where they listen if they want it changed.

T-Lone: Yes, that happens.

According to T-Annika, the problem is not only unclear quality criteria, but also the fact that there are different quality criteria from client to client:

T-Annika: The problem is often that some people want to follow the template stringently, while there are others who suddenly want to make their own rules, saying: "It should be like that and that and that, because we don't think it sounds nice when it's written like that or that." So, some of them have their own more or less good rules and others just want you to follow the templates, and there are so many different templates you have to follow. So, when you use a joint translation memory, it's suddenly a total mishmash.

The other professional translators also expressed their frustration with differing quality criteria from client to client: 
T-Cathrine: I think it makes a big difference whether it's something you get from a foreign client or if it's from Denmark [T-Jonas and T-Lone: Yes]. Especially because you have the possibility of arguing for something and saying "have a look at this, your final product will actually be improved if we change these things." Whereas, if you work with Chinese, Czechs or Americans, they just take it word-for-word.

T-Lone: Yes.

Moderator: You said that sometimes you get just a small part that needs translation, where you find some things that could be improved. Some terms that might be translated better. What do you do then? Do you have the possibility and time to try and talk to the end client?

T-Cathrine: I'd say it depends on the day, the task and the client. Based on the experience you have with the client, you might decide it isn't worth going back and saying something. But, of course, if you find something where you think, we have to point this out, then we usually write an email to the client while we're doing the translation to say: "Listen, we'd like the opportunity to change this." Sometimes we're allowed and sometimes not.

T-Lone: Exactly.

The translator group discussed the problems related to other agents making changes in their translation, sometimes without their knowledge:

T-Jonas: If you have another translation company between you and the client, then there is such a long way to the client; you don't know if it's the other translation company who has fiddled with it [the translation memory], or whether it's the end client who has done it. And then translation memories are swapped: in the end, you just grab a cup of coffee.

T-Torben: And then we get the problem I mentioned before; you send it back to the client who then makes some changes, says thanks for the work and then sends it on to the manufacturer, after which you don't know what has been changed. That means that the next time you get something from the same client, you risk making the same mistakes or at least things that the client isn't satisfied with. And then you risk them wondering why you can't understand what they want! But there's nothing to understand, because you haven't been informed.

In the latter situation, the translator is not informed of required changes and thus continues to make the same translation choices, which can potentially be damaging for the translator-client relationship and the translator's reputation.

\subsubsection{Problematic linguistic review at the DHMA}

All Danish PIL translations are linguistically reviewed by two reviewers at the DHMA prior to authorization. Both focus groups found that, at times, elements are corrected or changed unnecessarily, sometimes resulting in a change of meaning. Two main concerns were voiced, both relating to consistency and quality, i.e. that the two reviewers at the DHMA have different quality criteria and that their quality criteria change over time.

The expertise of the people in charge of the linguistic review at the DHMA is first called into question by T-Lone in the translator focus group:

T-Lone: Sometimes you run a risk when the client sends it to the DHMA because very often those conducting the linguistic review are medical students. I've experienced 
someone very stubbornly informing me that I couldn't use the Danish term stof because it referred to narcotics [the term can refer to narcotics, but it is also a generic term meaning some kind of substance].

*laughter*

T-Lone: And that's not very fortunate. ${ }^{*}$ laughs*. Those who conduct the linguistic reviews aren't always fully aware about what they're doing. And sometimes they just send it back to delay a process.

The problematic review process at the DHMA is supported by the pharmacist focus group:

P-Hanne: I'd also say that one of them is very intense in terms of making all sorts of corrections where it isn't exactly necessary [...]

Others: Yes.

Moderator: So when you get it back the person has made some changes?

P-Hanne: Yes.

Moderator: Okay.

P-Louise: That's actually very common.

This sequence shows the linguistic expertise of the people conducting the reviews being called into question; the pharmacists feel that unnecessary elements are corrected or even changed, resulting in the meaning being altered. In another sequence, P-Louise expresses her frustration about what she calls "the flavor of the month" in the linguistic review process:

P-Louise: The translations change according to what I'd call 'the flavor of the month' at the DHMA. And the two people there do their linguistic reviews very differently. You've probably noticed the same in your companies? ${ }^{*}$ Everybody nods or exclaims affirmatively*

This quote shows P-Louise's frustration with the lack of consistency in the review process, both expressed by a temporal inconsistency ("flavor of the month") and a person-specific inconsistency (the two people who conduct their linguistic reviews very differently). At a later stage, the person-specific inconsistency is exemplified by P-Hanne:

P-Hanne: Yes. One of them wants us to translate fatal [fatal] with letal [lethal], and the other one wants fatal.

P-Katja: Yes.

P-Hanne: And it can be a little difficult if you have products in both groups, because then you need to remember: that one wants letal; and that one wants fatal. It seems totally inconsistent that those two people can't agree on what they think.

Directly after this sequence, P-Vibeke argues for the time-wise inconsistency:

P-Vibeke: And sometimes she says that something has to be changed, only to say it must be changed back again next time.

Both groups focused on the PIL production process as an unwieldy bureaucratic mechanism with decisions being made far from the Danish context (e.g. the use of the EMA templates). However, the pharmacist focus group showed that individual 
and local circumstances also influence the PIL translation process. They repeatedly gave the example of a former reviewer at the DHMA who was more open to variation as long as the meaning remained intact and who also advocated proper localization or target-text orientation, with greater independence of the English original. It was felt that current DHMA reviewers were more rigid and that they had diverging opinions, complicating the translators' task:

P-Hanne: It depends on [...] the people who do the review of our PILs. Previously, there was a person who said: "But, if the meaning is exactly the same, then it doesn't have to be so exact." She isn't there anymore. It's much more rigid now.

Moderator: This was someone at the DHMA?

P-Hanne: Yes [...] it actually resulted in PILs that were better after she'd looked at them.

It is thus very important who the linguistic reviewers are as they have significant influence over the final translation and its level of comprehensibility.

\section{Discussion}

This focus group study clearly shows that translation competence is difficult to gauge if only PIL translation products are analyzed. Very early in the focus group analysis, it became obvious that intratextual translation challenges and their consequences for PIL comprehensibility played a minor role for the focus group participants compared to contextual challenges and constraints. Only a few categories emerged that related to linguistic challenges, whereas an extensive number of categories were contextual. The discussed constraints explain many of the problematic translation choices found in the previous PIL studies. These were often outside the PIL translators' power, and mainly related to the extensive legal authorization process. One example is the extensive amendments of small parts of the PILs, resulting in inconsistencies that are detrimental to comprehensibility - for example, mixing the use of complex expert medical terms and lay terms. Another example is the status of the source text, previously referred to by Askehave and Zethsen (2002) as a competing skopoi problem, where ensuring a fast and smooth approval procedure by staying close to the source text is valued higher than patient comprehensibility. This means that source text elements of detriment to comprehensibility are transferred. The constraints resulting from the influence of other agents, such as clients, resonate with previous studies. Dam and Zethsen's study of professional translators concluded that translation clients do not understand the importance of "involving the translator in the entire process" (Dam and Zethsen 2010: 202). Similarly, the professional translators of this study feel that they are not always sufficiently involved and their expertise not always valued. A similar result was found by Dam and Zethsen: the professional translators of their studies were not considered experts by other parties (2010) and they did not find a large degree of influence connected to their job (Dam and Zethsen 2011). According to Hönig (1998), in order to act responsibly, translators must be allowed the freedom to decide what is in their clients' best interests in co-operation with the clients. The professional translators in the focus group argue that they try to discuss PIL translation issues with the client: sometimes this is successful, whilst at other times, the client does not listen. One reason for this is that they do not understand the reasons why the translators want something changed. The translators also say that they 
sometimes feel it is not worth trying to contact the client apart from in very important cases, depending on the client and the experience they have with that client. According to Nord (2006: 30), if the client is unwilling to provide the necessary information, the client has to "take what they get," which is often a target text that may fit many different functions, but not necessarily one that fits all the receiver's needs. Such an approach also seems to be taken in PIL translation, when the professional translators feel their message falls on deaf ears. Such an approach is understandable in light of the temporal and financial constraints; however, it might lead to problematic PIL translations.

Naturally, a focus group study can only provide insights into the topics discussed by the participants who agreed to participate, which means it is possible to speculate whether other professional translators and pharmacists would have had very different opinions and comments. However, the recruited participants can be considered the most suitable as they are some of the most experienced PIL translators in Denmark, with several of them having translated between 200 and 2000 PILs.

Another potential issue is the relationship between attitude and action. It is not possible to know the relationship between what the participants say in the focus group interview and what happens in practice. It is well known that there are comprehensibility problems in PILs, and the fact that contextual constraints were given more focus compared to translators' own choices or abilities in relation to comprehensibility should be seen in this light. To gain an understanding of both attitude and action, one would need to conduct process studies, which log the process, such as key-stroke logging, as well as investigate the reasoning behind choices, such as think-aloud protocols or retrospective interviews, while, of course, keeping in mind the limitations of these methods. In light of the many contextual constraints, this would also have to be an authentic, workplace study.

Furthermore, as mentioned in the introduction to the focus group method (see section 3), group dynamics assist the data collection; however, the group situation can also have several effects on the group participants, such as conformity processes where participants adapt to each other and to the dominant consensus in the group, or polarization processes where different opinions in the group are made extreme or are polarized (Morgan 1997). Whether, and in which way, any of these group effects have influenced the two focus groups is a speculative question. It is impossible to give definite answers to this question, but some factors are relevant to mention. It is difficult to know whether dominant views or participants override any minority opinions; however, it should be noted that in the pharmacist group, two of the pharmacists were younger and more inexperienced with PIL translation than the three other more experienced pharmacists. These two pharmacists did not share as much information as the other three. In the translator group, four of the five translators knew each other. It is difficult to say whether their knowledge of each other influenced the group processes; as the professional translator business is quite small in Denmark, there might be issues that were not revealed in the focus group.

\section{Conclusion}

The focus group study revealed that translation competence is difficult to gauge in a study of PIL translation if only translation products are analyzed. The contextual 
environment has major consequences for the quality of the translation product. The identified constraints include the source text, legislative measures such as templates and national guidelines, temporal and financial constraints, and competing skopoi. Furthermore, other agents such as clients and reviewers exert a restricting influence. Thus, the translators are not always able to apply their translation competence and function as competent experts, even though they generally attempt to exercise their translation competence towards clients to ensure an optimal translation product. The professional translators seem comfortable exercising their expertise by educating clients on problematic choices, but often in vain, which means that they are not granted the necessary freedom to exercise this expertise. Therefore, in order to investigate translation competence outside controlled experiment settings, product studies must be combined with other methods, such as the focus group.

\section{NOTES}

1. The European Medicines Agency (EMA) uses the term Package Leaflet. I have opted for Patient Information Leaflet as this term refers both to the function and the receiver of the leaflet, rather than merely the location of the leaflet inside the medication package.

2. The names used here are pseudonyms. The $T$ in front of the name signifies Translator, and the $P$ in Table 2 signifies Pharmacist.

3. Master's degree program in International Business Communication, Translation and Interpreting Profile. This master's degree gives access to the protected title of state-authorized translator.

4. Master's degree program in English (Arts).

5. Master's degree program in Pharmacy.

\section{REFERENCES}

Alves, Fabio (2005): Bridging the Gap Between Declarative and Procedural Knowledge in the Training of Translators: Meta-Reflection Under Scrutiny. Meta. 50(4):1-25.

ANgELELLI, Claudia V (2006): Validating professional standards and codes: Challenges and opportunities. Interpreting. 8(2):175-193.

Askehave, Inger and Zethsen, Karen Korning (2000): Medical texts made simple - dream or reality? Hermes, Journal of Linguistics. 25:63-74.

Askehave, Inger and Zethisen, Karen Korning (2002): Translating for Laymen. Perspectives: Studies in Translatology. 10(1):15-29.

Askehave, Inger and Zethsen, Karen Korning (2003): Communication barriers in public discourse. Document Design. 4(1):23-42.

Askehave, Inger and Zethsen, Karen Korning (2010): "Check it out" - The constructions of patient empowerment in health promotion leaflets. In: Miguel F. RuIz GARRIDO, Inmacualda Fortanet and Juan Carlos Palmer, eds. English for Academic and Professional Purposes. Utrecht: Rodopi, 105-120.

Bloor, Michael, Frankland, Jane, Thomas, Michelle et al. (2001): Focus Groups in Social Research. London: Sage.

Braun, Virginia, and Clarke, Victoria (2006): Using thematic analysis in psychology. Qualitative Research in Psychology. 3(2):77-101.

Brinkmann, Svend and Kvale, Steiner (2009): InterViews. Learning the Craft of Qualitative Research Interviewing. 2nd ed. Los Angeles: Sage.

Chesterman, Andrew (1997): Memes of Translation: The Spread of Ideas in Translation Theory. Amsterdam: John Benjamins.

Consumers' Association (2000): Patient Information Leaflets: Sick Notes? London: Consumers' Association.

Dam, Helle Vrønning and Zethsen, Karen Korning (2010): Translator status: Helpers and opponents in the ongoing battle of an emerging profession. Target. 22(2):194-211. 
Dam, Helle Vrønning and Zethsen, Karen Korning (2011): The status of professional business translators on the Danish market: A comparative study of company, agency and freelance translators. Meta. 56(4):976-997.

Dickinson, David, Raynor, DK Theo and Duman, Mark (2001): Patient information leaflets for medicines: Using consumer testing to determine the most effective design. Patient Education and Counseling. 43(2):147-159.

European Parliament And Council (2001): Directive 2001/83/EC of the European Parliament and of the Council of 6 November 2001.

Even-Zohar, Itamar (1979): Polysystem theory. Poetics Today. 1(1-2):287-310.

Gentzler, Edwin and Tymoczko, Maria, eds. (2002): Translation and Power. Amherst: University of Massachusetts Press.

HALKier, Bente (2009): Fokusgrupper. 2 ed. Frederiksberg: Samfundslitteratur.

Harwood, Adam and Harrison, Jayne E. (2004): How readable are orthodontic patient information leaflets? Journal of Orthodontics. 31(3):210-219.

HöNIG, Hans G. (1998): Complexity, Contrastive Linguistics and Translator Training: Comments on Responses. In: Christina Schäffner, ed. Translation and Quality. Clevedon: Multilingual Matters, 83-89.

Koskinen, Kaisa (2008): Translating Institutions: An ethnographic Study of EU Translation. Manchester: St Jerome.

Milton, John and Bandia, Paul, eds. (2009): Agents of Translation. Amsterdam: John Benjamins.

Morgan, David L (1996): Focus Groups. Annual Review of Sociology. 22:129-152.

Morgan, David L (1997): Focus Groups as Qualitative Research. London: Sage.

Neubert, Albert (1994): Competence in Translation: a complex skill, how to study and how to teach it. In: Mary Snell-Hornby, Franz PöchHacker and Klaus KaIndL, eds. Translation Studies: An Interdiscipline. Amsterdam: John Benjamins, 411-420.

Nisbeth Jensen, Matilde (2013): Translators of Patient Information Leaflets: Translation experts or expert translators? A mixed methods study of lay-friendliness. PhD Dissertation, unpublished. Aarhus: Aarhus University.

Nisbeth Jensen, Matilde and Zethesen, Karen Korning (2012): Translation of Patient Information Leaflets: Trained translators and pharmacists-cum-translators - a comparison. In: Vicent Montalt and Mark Shuttleworth, eds. Translation and Knowledge Mediation in Medical and Health Settings. Linguistica Antverpiensia New Series. Themes in Translation Studies. 11:31-49.

Nord, Christiane (2006): Loyalty and fidelity in specialized translation. Confluencias. 4:29-41.

PACTE (2000): Acquiring Translation Competence: Hypotheses and Methodological Problems in a Research Project. In: Allison Beeby, Doris Ensinger and Marisa Presas, eds. Investigating Translation: Selected papers from the 4th International Congress on Translation, Barcelona, 1998. Amsterdam: John Benjamins, 99-106.

PACTE (2002): Exploratory Tests in a Study of Translation Competence. Conference Interpretation and Translation. 4(2):41-69.

PACTE (2003): Building a Translation Competence Model. In: Fabio Alves, ed. Triangulating Translation. Perspectives in Process Oriented Research. Amsterdam: John Benjamins, 43-66.

PACTE (2005): Investigating Translation Competence: Conceptual and Methodological Issues. Meta. 50(2):609-619.

PACTE (2009): Results and the validation of the PACTE translation competence model: acceptability and decision making. Across Languages and Cultures. 10(2):207-230.

PACTE (2011): Results of the validation of the PACTE translation competence model: translation project and dynamic translation index. In: Sharon O'BrIEN, ed. IATIS Yearbook 2010. London: Continuum, 30-53.

Pander MaAt, Henk and Lentz, Leo (2010): Improving the usability of patient information leaflets. Patient Education and Counseling. 80(1):113-119.

PyM, Anthony (2003): Redefining Translation Competence in an Electronic Age. In Defence of a Minimalist Approach. Meta. 48(4):481-497. 
RAYNOR, DK Theo (2007): The importance of medicines information for patients. Prescriber. 18(2):60-62.

Schjoldager, Anne and Zethsen, Karen Korning (2003): How Skopos is Established by the Professional Translator: Preliminary Results of a Focus Group. In: Andrejs Veisbergs, ed. The Third Riga Symposium on Pragmatic Aspects of Translation. Proceedings. Riga: University of Latvia \& Aarhus School of Business, 140-152.

Vermeer, Hans J (2004): Skopos and commission in translation action. In: Lawrence VenUti, ed. The Translation Studies Reader. London: Routledge, 227-238. 